\title{
From Refuge to Polis: Shifting the Rationale for Religiosity in Schools
}

\section{Don Dippo ${ }^{1}$}

\begin{abstract}
This article responds to Bruce Collet's article From Refuge to Polis: Shifting the Rationale for Religiosity in Schools." In this rejoinder my intention is to shift the discussion from school-as-refuge to school-as-polis and to ask whether the integration interests of recent immigrants and refugees might not be better served by a more inclusive approach to religiosity in schools that is less about collective exception and more about social transformation.
\end{abstract}

\section{Keywords}

Refugees, Religious Accommodation, Inclusive Education

Sorting out the appropriate relationship between religion and public schooling has never been as easy as the simple assertion of separation of church and state would imply (Haynes, 2009). In Sites of Refuge: Refugees, Religiosity, and Public Schools in the United States, Bruce Collet uses the concept of polyethnic group rights (Kymlicka, 1995) to make the case for accommodating the religious identities and religious expressions of immigrant and refugee students in public schools. He argues that, as "sites of refuge" where religious identities can be expressed, schools have the potential to play an important part in supporting integration processes of immigrants and refugees. The article centers on the extraordinary circumstances of forced migration and a recognition of the importance of religion in the lives of forced migrants, to make the case for religious accommodation in what are ostensibly secular public schools. The overarching concern of the article is with processes of integration. The claim is that "by guaranteeing the right to their societal culture, polyethnic rights comprise a viable framework for

\footnotetext{
${ }^{1}$ York University, Toronto, Ontario, Canada
} 
supporting immigrants and refugees in their integration into the United States" (Collet, 2009, p. 2). The case is clearly presented, well argued, and compelling and makes a significant contribution to ongoing policy discussions regarding an historically thorny but increasingly timely issue. That said, my intention in this rejoinder is to shift the discussion somewhat from school-as-refuge to school-as-polis and to ask whether the integration interests of recent immigrants and refugees might not be better served by a more inclusive approach to religiosity in schools that is less about collective exception and more about social transformation.

\section{The Case for Exception: Public School as Refuge}

One way (perhaps the most common way) of interpreting the state commitment to educational "neutrality" is to imagine schools as religion-free zones. To hold this view requires one to ignore the overwhelmingly Christian dimensions of mainstream cultural contexts in the United States and to set aside the obviously Christian origins of definitions of the school week and indeed the school year. Nonetheless, there are many who insist that liberalism and secularism demand that constraints and limitations be placed on the expression of religious identity in schools. Contrary to this view, Collet argues that for purposes of integration, exceptions to the "necessary constraints" on religious expression should be made for refugees. He bases this argument on the recognition, supported by extensive empirical research, of the centrality of religion for many people in migration and postmigration experiences. Not only does religion help to ameliorate trauma but it often plays a central role in resettlement and community building. This is not to say that Collet is indifferent to the larger project of social transformation. Indeed, citing Kymlicka, he makes the point that the very recognition of a polyethnic group "addresses the potential that ethnic groups have to contributing to diversity within the majority culture" (Collet, 2009, p. 24). Nor does it imply that there are not good reasons to recognize the unique circumstances of refugees and forced migrants. Rather my question is whether it might not be a better strategy to focus less on the extraordinary situation of the refugee- "a sort of 'flagship community' for migrants rights" (Collet, 2009, p. 24) -and place more emphasis on the benefits of an enlarged vision of more inclusive schools and a more inclusive society.

\section{The Case for Transformation: Public School as Polis}

Another perhaps less common way of interpreting the state commitment to educational "neutrality" is to imagine schools that allow for the expression of many religions rather than none (or just one). This shift enables us to think 
about the religion of the refugee not as something that requires an "exemption" from the principle of school neutrality but rather as something that makes an important contribution to religious liberty, inclusivity, and pluralism both in the school and in the larger society. Such a position emphasizes interaction and engagement as an important component of integration. It sees integration not as a one-way process whereby forced migrants and refugees learn to adapt to the meanings, values, and practices of the dominant culture. Instead, integration through interaction and engagement is about making new common meanings, values, and practices and transforming dominant cultures. In describing Hannah Arendt's conception of the "democratic person," Gert Biesta (2007) sets out an interesting description of the public sphere rich in implications for how we think about the place of religiosity in schools. Talking about subjectivity as a quality of human action and interaction, Biesta writes,

While we could refer to Arendt's position as a social conception of subjectivity-Arendt argues, after all, that we cannot be a subject in isolation-I prefer to call it a political conception. The main reason for this is that Arendt holds that my subjectivity is only possible in the situation in which others can be subjects as well. Not any social situation will therefore do. In those situations in which we try to control the responses of others or deprive others of the opportunity to begin, we cannot come into the world either, our subjectivity is not a possibility. Arendt relates subjectivity, in other words, to the life of the polis, the public sphere where we live-and have to live-with others who are not like us. It is here that we can see the link between Arendt's political conception of subjectivity and the idea of democracy, in that democracy can precisely be understood as the situation in which everyone has the opportunity to be a subject, in which everyone has the opportunity to act and, through their actions, bring their beginnings and initiatives into the world of difference and plurality. (Biesta, 2007, p. 8)

Bringing the conversation back to the question of school policy, could the polis be an appropriate metaphor for thinking about religiosity and public schooling? The Ontario Ministry of Education apparently thinks so and has recently produced a policy document entitled "Realizing the Promise of Diversity: Ontario's Equity and Inclusive Education Strategy" (Ontario Ministry of Education, 2009). The document is premised on an assumption of difference and plurality and a recognition that schools are indeed public spheres where we have to learn to live with others who are not like us. The document begins by defining three core concepts:

Diversity: The presence of a wide range of human qualities and attributes within a group, organization, or society. The dimensions of diversity 
include, but are not limited to, ancestry, culture, ethnicity, gender, gender identity, language, physical and intellectual ability, race, religion, sex, sexual orientation, and socio-economic status. (p. 4)

Equity: A condition or state of fair, inclusive, and respectful treatment of all people. Equity does not mean treating people the same without regard for individual differences. (p. 4)

Inclusive Education: Education that is based on the principles of acceptance and inclusion of all students. Students see themselves reflected in their curriculum, their physical surroundings, and the broader environment, in which diversity is honoured and all individuals are respected. (p. 4)

The document sets out a vision of an inclusive education system (p. 10), describes the guiding principles that are to inform the inclusive education strategy (p. 11), and establishes leadership, policy, and accountability as core priorities (p. 12). The framework is comprehensive and intended to address the range of socially constituted significant human differences. With respect to religious difference, the strategy directs every school board in Ontario to "have religious accommodation guidelines in place, and communicate these guidelines to the school community" by 2009-2010 (p. 21). The Toronto District School Board (n.d.) is singled out in the strategy document as a board whose "policies embed the principles of fairness, equity, and inclusive education and include comprehensive guidelines for religious accommodation designed to ensure that students and staff can observe the tenets of their faith free from harassment or discrimination" (p. 16).

The "Guidelines and Procedures for Religious Accommodations" of the Toronto District School Board (Toronto District School Board, n.d.) begin by outlining the legislative and policy context within which the guidelines and procedures have been developed (not unlike the American Constitution's First Amendment commitment to "free exercise"):

The Canadian Charter of Rights and Freedoms protects freedom of religion. The Ontario Human Rights Code protects an individual's freedom from discriminatory or harassing behaviour based on religion. (p. 1)

The Ontario Human Rights Policy Guidelines on Creed and the Accommodation of Religious Observances defines accommodation as a duty corresponding to the right to be free from discrimination. (p. 2)

The duty to accommodate applies to students and staff in Toronto schools and covers areas that include but are not limited to observation of major religious holy days and celebrations, school opening or closing exercises, prayer, dietary requirements, fasting, religious attire, modesty requirements in physical education, and participation in daily activities and curriculum (p. 4). The 
document makes clear that the duty to accommodate is not absolute-that accommodations apply to individuals and not to whole classes or to classroom practices in general and that the board cannot accommodate religious values and beliefs that conflict with the Ontario Human Rights Code or with board policies (p. 8). That said, the Guidelines and Procedures are intended to support a flexible and commonsense approach to dealing with questions of religion and schooling and express the hope that a commitment to accommodation and dialogue with members of diverse religious communities "will help to build an environment of mutual respect and understanding" (p. 1).

A policy does not make a community harmonious. Still, it does provide a place to turn for support for activities and initiatives that might make schooling more inclusive, more participatory, and, in Arendt's formulation, more democratic. As George Dei puts it,

Inclusion is not bringing people into what already exists; it is making a new space, a better space for everyone. (Dei, 2006, cited in Ontario Ministry of Education, 2009, p. 2)

\section{Declaration of Conflicting Interests}

The author declared no potential conflicts of interests with respect to the authorship and/or publication of this article.

\section{Funding}

The author received no financial support for the research and/or authorship of this article.

\section{References}

Biesta, G. (2007). Education and the democratic person: Toward a political conception of democratic education. Teachers College Record, 109, 740-769.

Haynes, C. (2009, February). Religious liberty in public schools-at long last. Teachers College Record, 16, 1.

Kymlicka, W. (1995). Multicultural citizenship: A liberal theory of minority rights. Oxford, UK: Clarendon.

Ontario Ministry of Education. (2009). Realizing the promise of diversity: Ontario's equity and inclusive education strategy. Toronto: Author.

Toronto District School Board. (n.d.). Guidelines and procedures for religious accommodations. Toronto, Ontario, Canada: Author.

\section{Bio}

Don Dippo is Professor and Associate Dean of Education at York University, Toronto, Canada. He is on the Executive Committee of the Centre for Refugee Studies and is interested in issues related to education and forced migration. 